\title{
Design of Industrial Water Cooled Chiller for Recycle Cyclohexane in Polyethylene Plant
}

\author{
Jackson Gunorubon Akpa, Kenneth Kekpugile Dagde, Nsisong Basil Inyang \\ Department of Chemical/Petrochemical Engineering, Rivers State University, Port Harcourt, Nigeria \\ Email: akpa.jackson@ust.edu.ng, dagde.kenneth@ust.edu.ng, basilbazo@yahoo.com
}

How to cite this paper: Akpa, J.G., Dagde, K.K. and Inyang, N.B. (2019) Design of Industrial Water Cooled Chiller for Recycle Cyclohexane in Polyethylene Plant. Advances in Chemical Engineering and Science, 9, 143-158.

https://doi.org/10.4236/aces.2019.92011

Received: February 13, 2019

Accepted: March 30, 2019

Published: April 2, 2018

Copyright () 2019 by author(s) and Scientific Research Publishing Inc. This work is licensed under the Creative Commons Attribution International License (CC BY 4.0).

http://creativecommons.org/licenses/by/4.0/

\begin{abstract}
The research was aimed at providing water for cooling recycled cyclohexane in polyethylene plant to $15^{\circ} \mathrm{C}$. This research could be redounding to the benefit of polyethylene plants that are using solution based polymerization technique. A chiller unit of $630 \mathrm{~T}$, which has compressor power input of 378.33 $\mathrm{kW}$ and can provide chilled water capable of cooling recycle cyclohexane to $15^{\circ} \mathrm{C}$, was designed using Aspen Hysys version 7.1. Four different refrigerants were tested to know the best fit refrigerant for the design and the best among them was R134a. The designed chiller has a coefficient of performance of 6.3 and a capacity greater than that of the defective chiller (550 TR). Unlike the defective chiller, with the increased cooling capacity and corresponding increase in compressor power from $296 \mathrm{~kW}$ to $378.6 \mathrm{~kW}$, it could discharge chilled water capable of cooling recycle cyclohexane from $38^{\circ} \mathrm{C}$ to $15^{\circ} \mathrm{C}$ without tripping of the unit. With this design, ethylene absorption rate could increase to $40 \mathrm{~T} / \mathrm{h}$. Evaporator and condenser were designed and duties were $2166.39 \mathrm{KJ} / \mathrm{sec}$ and $2544.72 \mathrm{KJ} / \mathrm{sec}$ respectively. A thermostatic expansion valve with flow coefficient of $46.17 \mathrm{gpm}$ was designed. The designed suction and discharge pressure were $414 \mathrm{kpa}$ and $1053 \mathrm{kpa}$ respectively while condenser temperature of $40^{\circ} \mathrm{C}$ was used for the design. The cooling of recycle cyclohexane from $38^{\circ} \mathrm{C}$ to $15^{\circ} \mathrm{C}$ using the chilled water supplied by the designed chiller was simulated using Aspen Hysys.
\end{abstract}

\section{Keywords}

Chiller, Compressor, Evaporator, Condenser, Expansion Valve

\section{Introduction}

Polyethylene production can be achieved using solution based polymerization technology [1], slurry method [2] or gas phase technology [3]. In solution based method, a solvent is used to absorb ethylene and this solvent does not take part 
in reaction but is however recovered and recycled in other to save cost. Example of such solvent is cyclohexane.

Ethylene absorption is highly exothermic and the temperature of the recycle cyclohexane affects the equilibrium absorption temperature [1]. In Eleme Petrochemicals, recycle cyclohexane at $7 \mathrm{Kg} / \mathrm{cm}^{2}$ is cooled from $180^{\circ} \mathrm{C}$ to about $35^{\circ} \mathrm{C}$ using series of heat exchangers. Some of the heat exchangers use cooling water supplied at $32^{\circ} \mathrm{C}$. In a quest to further cool the cyclohexane so as to improve ethylene absorption, a chiller was introduced and this only helped to drop the recycle cyclohexane temperature to $20^{\circ} \mathrm{C}$. Efforts to cool further to $17^{\circ} \mathrm{C}$ resulted in tripping of the chiller and the unit eventually broke down.

The aim of this research was to design a chiller capable of supplying water for cooling the recycle cyclohexane to $15^{\circ} \mathrm{C}$. A chiller is one of the heat transfer equipment and it employs the principles of vapour compression cycle.

The objectives of the project include: simulation of the cooling of cyclohexane from $38^{\circ} \mathrm{C}$ to $15^{\circ} \mathrm{C}$, using Hysys, to get the chiller water requirements, test with different refrigerants to get the best fit refrigerant for the design, development of algorithm for the design and design of the proposed chiller based on the optimum chiller water parameter requirements and best fit refrigerant.

\section{Materials and Methods}

\subsection{Materials}

The materials used for this report includes P-h diagram for R134a, R125, R152a \& R1270 respectively; ASHRAE handbooks, Handbook of Air Conditioning \& Refrigeration; Process Technology manual, software (Aspen Hysys, version 7.1) and input data. The input data, which were gotten from the Plant, includes cyclohexane flow rate, temperature \& pressure; cooling water pressure and temperature.

\subsection{Methods}

To achieve the aim of this research, Aspen Hysys software, version 7.1, which used the principles of mass \& energy conservations, principles of heat transfer and Thermodynamics to generate results, was used. A design tolerance of $10 \%$ was used in this work and a steady state simulation and design procedure was applied. The following assumptions were made:

1) Potential and kinetic energy effect were negligible

2) Evaporator and condenser were at constant pressure

3) Evaporator outlet was saturated vapour while condenser outlet was saturated liquid

4) The vapour compression cycle was at steady state.

5) Adiabatic process occurs at the expansion valve

6) The chiller was considered to be an ideal vapour compression refrigeration cycle and thus, the compression process was isentropic.

Figure 1 is the chiller loop with cyclohexane cooling loop. The path "abcd" 
indicates the refrigeration loop. At evaporator, water used in cyclohexane cooling loss heat to the refrigerant and return to the plate heat exchanger as chilled water at a lower temperature for cooling the recycled cyclohexane while the refrigerant gain heat and vaporized. The compressor lifts the refrigerant to the condenser with increase in energy. At the condenser, the heat removed from the water at evaporator is rejected and the condensed refrigerant is sent back to the evaporator through metering device to complete the vapour compression cycle.

\subsubsection{Chiller Water Process Parameter Requirement}

The process of cooling $200 \mathrm{~T} / \mathrm{hr}$ of cyclohexane from $38^{\circ} \mathrm{C}$ to $15^{\circ} \mathrm{C}$ was simulated using Aspen Hysys to determine the volume of water and the temperature of water going to chiller as shown in Figure 1. The sensible heat of the cooling process was estimated as follows [4]:

$$
Q_{s}=m_{s} C p_{s}\left(t_{s o}-t_{s 1}\right)
$$

where, $Q_{s}$ is the rate of heat loss by the hot cyclohexane, $m_{s}$ is the mass flow rate of cyclohexane, $C P_{s}$ is the specific heat capacity of cyclohexane at mean temperature, $t_{s o}$ is the temperature of cyclohexane after cooling and $t_{s i}$ is the inlet temperature of cyclohexane.

In other to estimate the water requirement, energy balance on the plate heat exchanger was done:

$$
Q_{s}=m_{w} C p_{w}\left(t_{w o}-t_{w i}\right)
$$

where, $t_{w o}$ is the temperature of the water returned to the chiller evaporator after cyclohexane cooling, which is to be determined (as shown in Figure 1) and $t_{w i}$ is temperature of the chilled water with a value not greater than $15^{\circ} \mathrm{C}$.

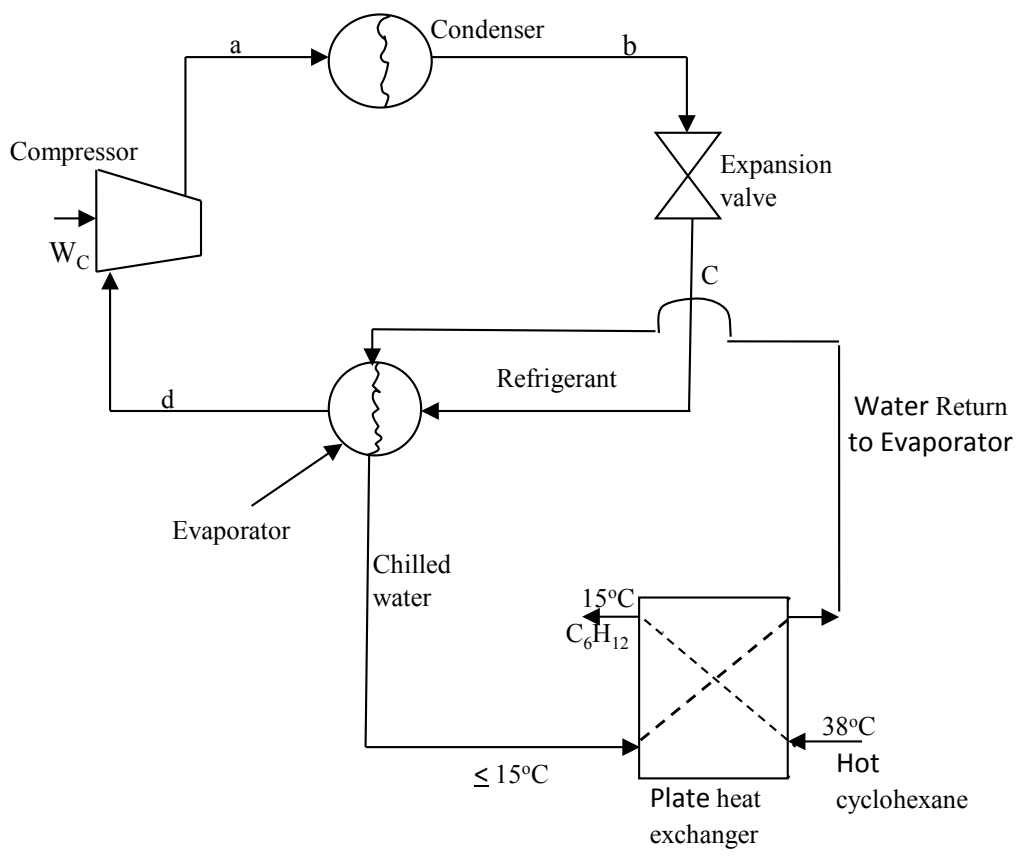

Figure 1. Chiller and cyclohexane cooling loop. 


\subsubsection{Selection of Refrigerant}

Simulation of the vapour compression cycle and cyclohexane cooling were done at evaporator temperature of $5^{\circ} \mathrm{C}, 8^{\circ} \mathrm{C}, 10^{\circ} \mathrm{C}, 12^{\circ} \mathrm{C}, \& 13^{\circ} \mathrm{C}$ to respectively to determine the refrigerant that will require least energy input in the compressor. The refrigerants used were 1,1,1,2-tetraflouroethane (R134a), 1,1,1,2,2- pentaflouroethane (R125), propylene (R1270) \& 1,1-diflouroethane (R152a). The volume of the refrigerant required, compressor power requirement and temperature of water returned to evaporator were noted.

\subsubsection{Chiller Design}

Using the cyclohexane cooling simulation results, the cooling load of the chiller was calculated using Equation (3) [5].

$$
Q_{\text {evap }}=V \rho C p_{w}\left(T_{\text {in }}-T_{\text {out }}\right)
$$

The cooling load was converted to chiller capacity in refrigeration tons (TR) using a conversion factor of $1 \mathrm{TR}$ is $3.5 \mathrm{~kW}$ [6].

The ideal P-h diagram for the chiller is shown in Figure 2. It was used to determine the thermodynamic properties of the refrigerant at stage 1 (compressor suction), stage 2 (compressor discharge), stage 3 (condenser outlet) and stage 4 (expansion valve outlet/ evaporator inlet.

\section{1) Compressor Design}

Since the compression process is isentropic, the discharge temperature was calculated using the temperature variation between stages in isentropic process.

$$
T_{d}=T_{S}\left[r^{\left(\frac{\gamma-1}{\gamma}\right)}\right]
$$

In this work, the discharge temperature does not exceed $107^{\circ} \mathrm{C}$ because the discharge temperature should be less than the critical temperature of refrigerant [7].

Using Figure 2, the compressor energy input could be determined as follows

$$
W_{c}=h_{2}-h_{1}
$$

From the definition of enthalpy, Equation (5) could be transformed as [8]

$$
W_{c}=\dot{m} C_{\mathrm{Pr}}\left(T_{2}-T_{1}\right)
$$

To determine the isentropic efficiency of the designed compressor, isentropic head was estimated as [9]

$$
W_{\text {isen }}=C p_{R}\left(T_{2}^{\text {rev }}-T_{1}\right)
$$

To get $T^{\text {rev }}$, the compression was assumed reversible and the entropy of isentropic process was zero [4]

$$
\Delta S=C p \ln \left(\frac{T_{2}^{r e v}}{T_{1}}\right)-R \ln \left(P_{2} / P_{1}\right)=0
$$

The isentropic efficiency of the compressor was calculated using Equation (9) while the compressor power was estimated using Equation (10) [10]. 


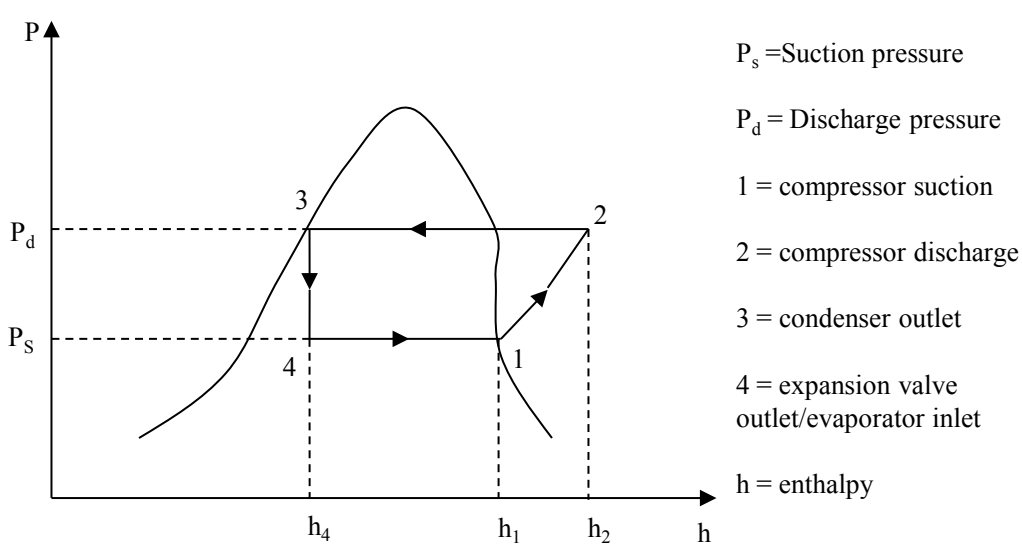

Figure 2. Ideal P-h diagram for the chiller.

$$
\begin{gathered}
\eta_{\text {isen }}=\frac{W_{\text {isen }}}{W_{s}} \\
\text { Power }=\dot{m} C_{\mathrm{Pr}_{\mathrm{r}}}\left(T_{2}-T_{1}\right)
\end{gathered}
$$

In this study, an isentropic efficiency range of $70 \%-85 \%$ was used [9].

\section{2) Evaporator and Condenser Design}

The chiller was designed using a condenser temperature of $40^{\circ} \mathrm{C}$ and evaporating temperature of $10^{\circ} \mathrm{C}$. The type of evaporator designed was flooded water-cooled shell and tube heat exchanger [11]. The tube side fluid was water while the refrigerant, R134a, was the shell side fluid. The condenser was shell and tube.

Taking energy balance on the evaporator, the heat transfer rate can be estimated as shown on Figure 2.

$$
Q_{\text {evap }}=m\left(h_{1}-h_{4}\right)
$$

The area of evaporator required for heat transfer was estimated using Equation (12) while the number of tubes was estimated using Equation (14) [12].

$$
Q_{\text {evap }}=U A \Delta T
$$

The range of values of " $U$ " in Equation (12) in this study was $1080-3600 \mathrm{~kJ} / \mathrm{h}$ $\mathrm{m}^{2} \cdot \mathrm{C}\left(300-1000 \mathrm{~W} / \mathrm{m}^{2} \cdot \mathrm{K}\right)$ for evaporator [13] and $3600-14,400 \mathrm{~kJ} / \mathrm{h} \mathrm{m}^{2} \cdot \mathrm{C}$ $\left(1000-4000 \mathrm{~W} / \mathrm{m}^{2} \cdot \mathrm{K}\right)$ for condenser [11].

The log mean temperature difference (LMTD) was evaluated as shown below [11].

$$
\begin{gathered}
\Delta T=\frac{T D_{1}-T D_{2}}{\ln \left(\frac{T D_{1}}{T D_{2}}\right)} \\
N_{t}=\frac{A}{\pi d_{o}^{2}}
\end{gathered}
$$

Using Figure 2, the heat transferred in the condenser can be established by taking energy balance at the condenser [14]. 


$$
Q_{\text {cond }}=m\left(h_{2}-h_{3}\right)
$$

\section{3) Metering Device}

At the valve, the refrigerant exists as saturated liquid (f) and saturated vapour (g) due to the flashing action. The dryness fraction of the refrigerant was denoted by " $X$ ". To get the dryness fraction of the refrigerant at the valve outlet, the enthalpy of the refrigerant was obtained as [7]

$$
h_{4}=h_{f}+x_{4}\left(h_{g}-h_{f}\right)
$$

where, $h_{f}$ and $h_{g}$ were gotten from chart (16)

From Figure 2, the coefficient of performance of the chiller can be determined as:

$$
C O P=\frac{h_{1}-h_{4}}{h_{2}-h_{1}}
$$

For this study, the value of COP was considered to be greater than 5.7 since the Carnot COP of the chiller was 5.7.

\subsection{Solution Technique}

The chiller was designed using Aspen Hysys simulator. The following algorithm was developed as solution techniques (Figure 3 ).

\section{Results and Discussion}

\subsection{Cyclohexane Cooling Simulation Results}

The results of the simulation of the cooling of the cyclohexane are as shown in Table 1. The result suggests that the temperature of water returned to the chiller is $31.65^{\circ} \mathrm{C}$. To cool $200 \mathrm{~T} / \mathrm{h}$ cyclohexane from $38^{\circ} \mathrm{C}$ to $15^{\circ} \mathrm{C}$ using $120 \mathrm{~m}^{3} / \mathrm{h}$ of water, the water temperature is $15^{\circ} \mathrm{C}$. This is because the temperature approach of the heat exchanger is $0^{\circ} \mathrm{C}$. A water flow rate of $120 \mathrm{~m}^{3} / \mathrm{hr}$ was used because the maximum rating of the pump supplying water to the chiller is $135 \mathrm{~m}^{3} / \mathrm{hr}$.

\subsection{Choice of Refrigerant}

\subsubsection{Effect of Evaporator Temperature on Compressor Power}

Figure 4 shows how the compressor power input vary with evaporator temperature for all the refrigerants used. It indicates that R134a was the best fit refrigerant for the design since it had the least compressor power input at each respective evaporator temperature.

Increased in evaporator temperature from $5^{\circ} \mathrm{C}$ through $13^{\circ} \mathrm{C}$ reduced the compressor power input for all the refrigerants due to drop in compression ratio which reduced the compressor work as shown in Figure 4.

This effect was maximum when R134a was used; thus, R134a is best fit for the design.

Evaporating temperature of less than $5^{\circ} \mathrm{C}$ was not considered to avoid freezing of the chilled water inside the tubes of evaporator; while evaporating temperature greater than $13^{\circ} \mathrm{C}$ was not considered to avoid temperature cross. 


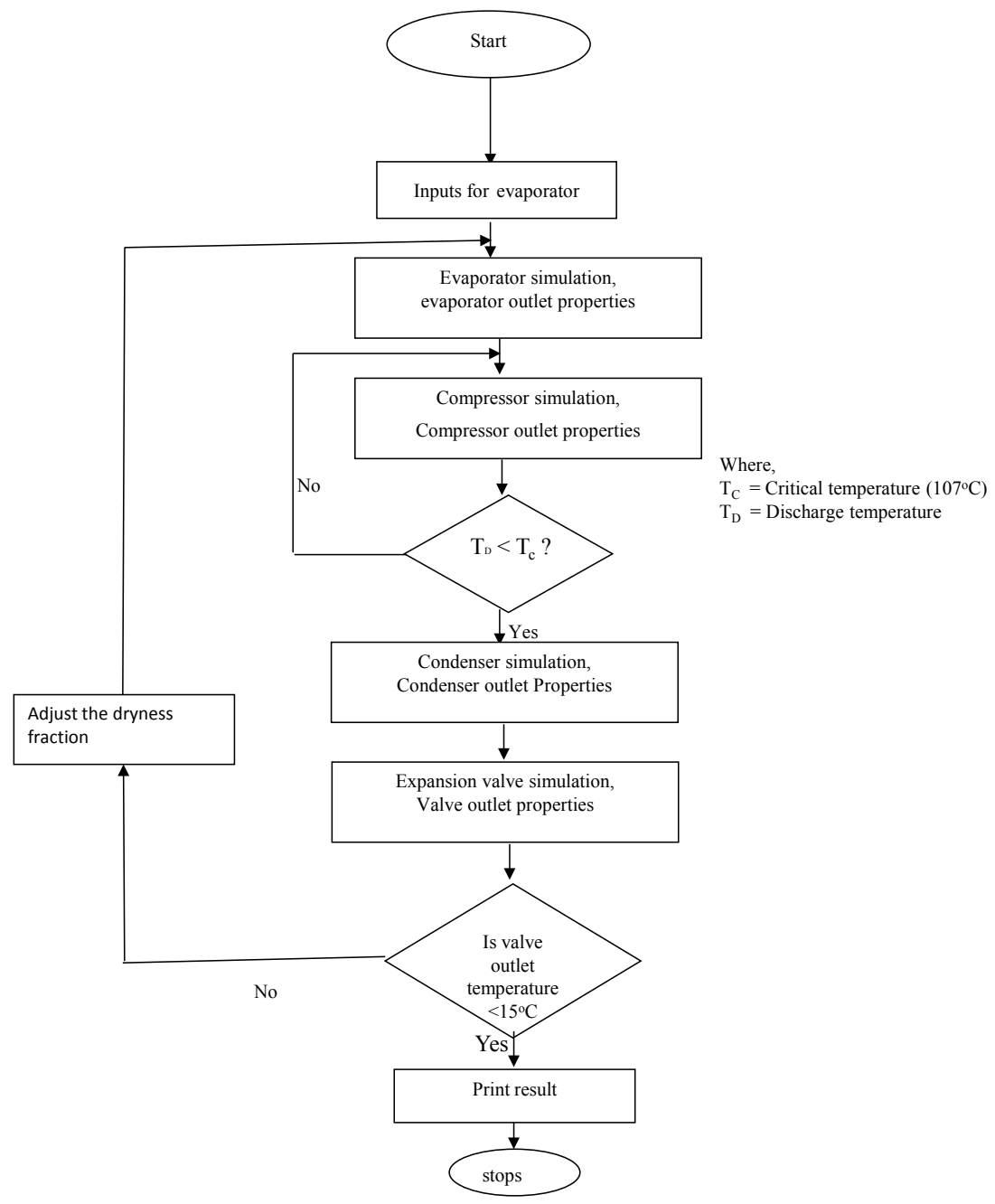

Figure 3. Algorithm of the chiller design.

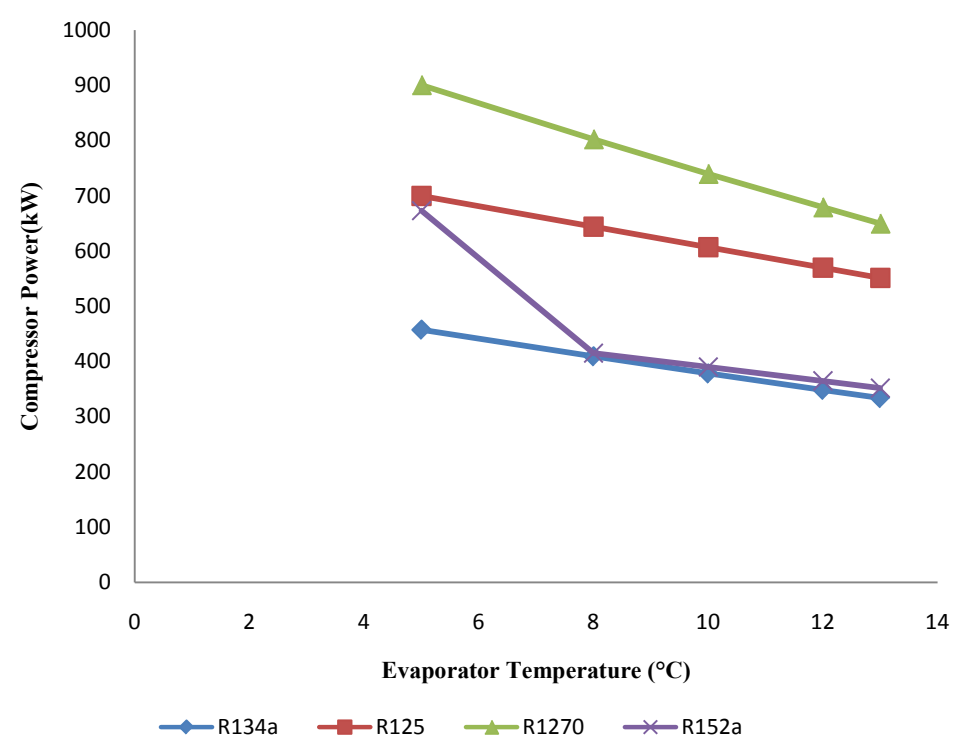

Figure 4. Effects of evaporator temperature on compressor power input for different refrigerants. 
Table 1. Process requirement of chiller water.

\begin{tabular}{ccc}
\hline Parameter & Existing & Simulation \\
\hline Water Flow-rate $\left(\mathrm{m}^{3} / \mathrm{h}\right)$ & 103 & 120.00 \\
Chilled-water temperature $\left({ }^{\circ} \mathrm{C}\right)$ & 20.00 & 15.00 \\
Water returned temperature $\left({ }^{\circ} \mathrm{C}\right)$ & 27.30 & 31.65 \\
Cyclohexane flow $(\mathrm{T} / \mathrm{h})$ & 200.00 & 200.00 \\
Cyclohexane temperature $\left({ }^{\circ} \mathrm{C}\right)$ & 35.00 & 38.00 \\
\hline
\end{tabular}

\subsubsection{Effect of Compressor Duty on Coefficient of Performance}

Figure 5 shows the effect of compressor duty on coefficient of performance for the different refrigerants used. The best fit refrigerant for the design was 1,1,1,2-tetrafluoraethane (R134a) since it required the least compressor power as shown on Figure 5. A chiller with less power input had high coefficient of performance and is cost effective [6]. R134a required a compressor power of 378.1 $\mathrm{KW}$ at $10^{\circ} \mathrm{C}$ while R152a required $390 \mathrm{~kW}$ compressor power at $10^{\circ} \mathrm{C}$ since the discharge temperature was higher when R152a was used.

Figure 5 also show that the coefficient of performance of a chiller increased with decreased in compressor power because coefficient of performance is the ratio of quantity of energy absorbed in evaporator to the energy input of the refrigeration cycle. R134a has the highest coefficient of performance of 6.49 since it had the least compressor input of $333.6 \mathrm{~kW}$ as shown in Figure 5.

\subsection{Chiller Design Results}

The summary of the results of chiller designed is shown in Table 2 . The capacity of the designed chiller is 630 Refrigeration Tons. 7,799,004 kJ/h of heat could be removed when the chiller water was cooled from $31.65^{\circ} \mathrm{C}$ to $15^{\circ} \mathrm{C}$ at the evaporator using R134a. Electrical power of $379 \mathrm{~kW}$ is needed by the compressor to expand the $42.2 \mathrm{~m}^{3} / \mathrm{h} \mathrm{R} 134 \mathrm{a}$ from $10^{\circ} \mathrm{C}$ to a designed temperature of $49.53^{\circ} \mathrm{C}$.

The type of compressor is centrifugal because of the high volume of refrigerant that is needed in the vapour compression cycle.

\subsubsection{Compressor Design Results}

Table 3 shows the compressor sizing results gotten from Hysys. The power input of the designed compressor was $378.6 \mathrm{kw}$ while it had adiabatic efficiency of $75 \%$. The compressor had an adiabatic head of $1995 \mathrm{~m}$. This high power consumption was as a result of increase in evaporator duty and refrigerant flow. The maximum discharge temperature of the designed compressor was satisfactory as it was less than the critical temperature of refrigerant which is $107^{\circ} \mathrm{C}$. The compressor was single stage because the compressor ratio was less than 4.0 [11].

\subsubsection{Evaporator and Condenser Design Results}

Table 4 shows that a design heat duty of 7,799,004 kJ/hr was required in the evaporator of this vapour compression cycle. The evaporator design temperature was $10^{\circ} \mathrm{C}$. This was because for a flooded water-cooled evaporator, the tempera- 
ture approach, which is the difference between the evaporating temperature and the chilled water outlet temperature, should be $3.3^{\circ} \mathrm{C}-5.6^{\circ} \mathrm{C}[6]$. The tube side outlet temperature was $15^{\circ} \mathrm{C}$ because the design was made at a worse case scenario of a temperature approach of the plate cooler, where the cooling of cyclohexane was done, at $0^{\circ} \mathrm{C}$.

The area of heat transfer was $288 \mathrm{~m}^{2}$ as compared to that of defective chiller which is $244 \mathrm{~m}^{2}$ (from vendor diagram) and the evaporator had 764 tubes. This area increase was as a result of the rise in heat duty.

Table 5 suggests that the condenser duty required for the design was $9,167,040 \mathrm{~kJ} / \mathrm{hr}$ and a condensing temperature of $40^{\circ} \mathrm{C}$ was used because as a rule of thumb, the condenser temperature is $10^{\circ} \mathrm{C}-15^{\circ} \mathrm{C}$ above ambient temperature [15].

The overall heat transfer coefficient of the condenser was $3796 \mathrm{~kJ} / \mathrm{h}-\mathrm{m}^{2} \mathrm{C}$ and the area of heat transfer was $332.5 \mathrm{~m}^{2}$ as compared to that of the defective chiller that was $319 \mathrm{~m}^{2}$. The total number of tubes of the designed condenser was 882 .

To avert the effect of corrosion, carbon steel was used for shell design.

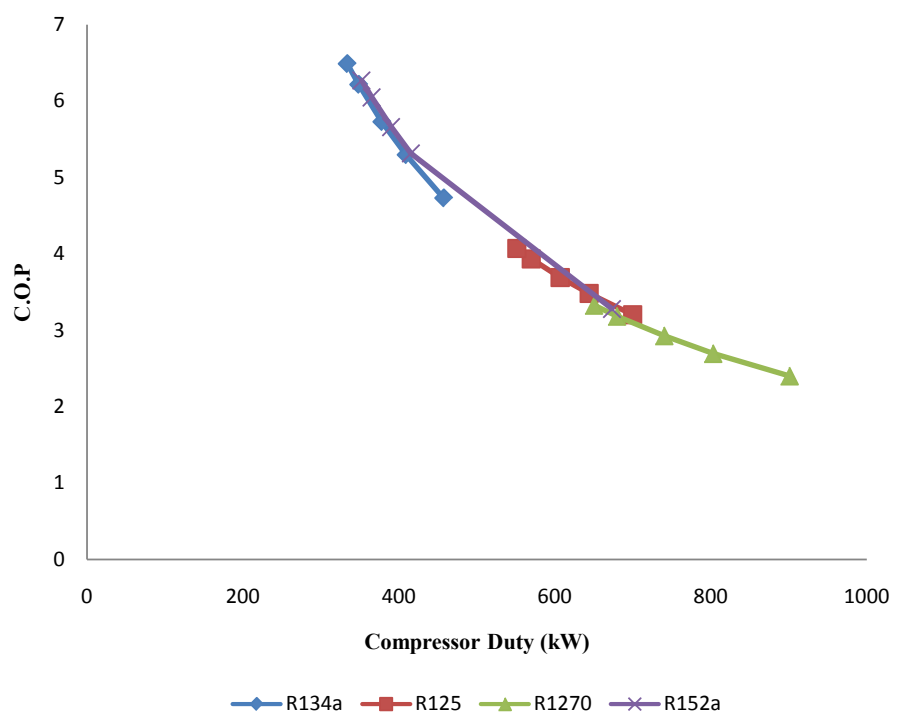

Figure 5. Effect of compressor duty on coefficient of performance for different refrigerants.

Table 2. New chiller specifications.

\begin{tabular}{cc}
\hline Designed Parameters and their Units & Values \\
\hline Chiller Capacity $(\mathrm{TR})$ & 630 \\
Cooling Load $(\mathrm{kJ} / \mathrm{h})$ & $7,799,004$ \\
Power $(\mathrm{kW})$ & 378 \\
Refrigerant flow $\left(\mathrm{m}^{3} / \mathrm{h}\right)$ & 42.2 \\
Suction Temperature $\left({ }^{\circ} \mathrm{C}\right)$ & 10 \\
Discharge Temperature $\left({ }^{\circ} \mathrm{C}\right)$ & 49.53 \\
Refrigerant & R134a \\
Type & Centrifugal \\
\hline
\end{tabular}


Table 3. Compressor sizing results.

\begin{tabular}{cc}
\hline Parameter & Value \\
\hline Power consumed $(\mathrm{kW})$ & 378.60 \\
Adiabatic efficiency $(\%)$ & 75.00 \\
Adiabatic head $(\mathrm{m})$ & 1995.00 \\
Suction pressure $(\mathrm{kPa})$ & 414.20 \\
Discharge pressure $(\mathrm{kPa})$ & 1053.00 \\
Flow rate $\left(\mathrm{m}^{3} / \mathrm{h}\right)$ & 42.070 \\
Suction temperature $\left({ }^{\circ} \mathrm{C}\right)$ & 10.00 \\
Discharge temperature $\left({ }^{\circ} \mathrm{C}\right)$ & 49.53 \\
Compressor type $/$ stages & Centrifugal $/$ single stage \\
\hline
\end{tabular}

Table 4. Evaporator sizing results.

\begin{tabular}{|c|c|}
\hline Parameter & Value \\
\hline Evaporator duty $(\mathrm{kJ} / \mathrm{h})$ & $7,799,004$ \\
\hline Overall coefficient of heat & 2495.00 \\
\hline \multicolumn{2}{|l|}{ Transfer $\left(\mathrm{kJ} / \mathrm{h}-\mathrm{m}^{2}-\mathrm{C}\right)$} \\
\hline Area of heat transfer $\left(\mathrm{m}^{2}\right)$ & 288.00 \\
\hline Number of tubes & 764.00 \\
\hline Tube internal diameter (mm) & 16.00 \\
\hline Tube external diameter (mm) & 20.00 \\
\hline Tube length (m) & 6.00 \\
\hline Tube thickness (mm) & 2.00 \\
\hline Number of shell passes & 1 \\
\hline Number of tube passes & 2 \\
\hline Shell diameter (mm) & $774 \mathrm{~mm}$ \\
\hline Tube layout angle & Triangular (30 degrees) \\
\hline Tube pitch (mm) & 25.00 \\
\hline Baffle spacing $(\mathrm{mm})$ & 309.00 \\
\hline Tube side inlet temperature $\left({ }^{\circ} \mathrm{C}\right)$ & $31.48^{\circ} \mathrm{C}$ \\
\hline Tube side outlet temperature $\left({ }^{\circ} \mathrm{C}\right)$ & $15.00^{\circ} \mathrm{C}$ \\
\hline Tube side pressure $(\mathrm{kPa})$ & 350.00 \\
\hline Shell side pressure $(\mathrm{kPa})$ & 421.2 \\
\hline Water flow rate $\left(\mathrm{m}^{3} / \mathrm{h}\right)$ & 120.0 \\
\hline Refrigerant flow rate $\left(\mathrm{m}^{3} / \mathrm{h}\right)$ & 42.1 \\
\hline Material for tube construction & Copper \\
\hline
\end{tabular}


Table 5. Condenser sizing results.

\begin{tabular}{|c|c|}
\hline Parameter & Value \\
\hline Condenser duty $(\mathrm{kJ} / \mathrm{h})$ & $9,167,040$ \\
\hline Overall coefficient foe hat transfer $\left(\mathrm{kJ} / \mathrm{h}-\mathrm{m}^{2}-\mathrm{C}\right)$ & 3796.00 \\
\hline Area of heat transfer $\left(\mathrm{m}^{2}\right)$ & 332.50 \\
\hline Number of tubes & 882 \\
\hline Tube internal diameter (mm) & 16.00 \\
\hline Tube external diameter $(\mathrm{mm})$ & 20.00 \\
\hline Tube material & Copper \\
\hline Number of shell passes & 1 \\
\hline Number of tube passes & 2 \\
\hline Shell diameter (mm) & 820 \\
\hline Material for shell construction & Carbon steel \\
\hline Tube layout angle & Triangular (30 degrees) \\
\hline Tube pitch (mm) & 50.00 \\
\hline Baffle spacing $(\mathrm{mm})$ & 331.00 \\
\hline Tube length (m) & 6 \\
\hline Shell side pressure $(\mathrm{kPa})$ & 1053 \\
\hline Tube side pressure $(\mathrm{kPa})$ & 350 \\
\hline Shell side inlet temperature $\left({ }^{\circ} \mathrm{C}\right)$ & 49.53 \\
\hline Shell side outlet temperature $\left({ }^{\circ} \mathrm{C}\right)$ & 40.00 \\
\hline Cooling water inlet temperature $\left({ }^{\circ} \mathrm{C}\right)$ & 30.00 \\
\hline Cooling water outlet temperature $\left({ }^{\circ} \mathrm{C}\right)$ & 36.51 \\
\hline Cooling water flow $\left(\mathrm{m}^{3} / \mathrm{h}\right)$ & 327.2 \\
\hline
\end{tabular}

\subsubsection{Expansion Valve Design Results}

Table 6 shows the expansion valve sizing results. For this design, thermostatic expansion valve was considered. The valve has a flow coefficient $\left(\mathrm{C}_{\mathrm{v}}\right)$ of 46.17 gpm at $50 \%$ opening.

The flow rate through the valve was $5.22 \times 10^{4} \mathrm{~kg} / \mathrm{h}$ while the pressure drop of the valve was $597.1 \mathrm{kPa}$.

\subsection{Comparison of the Propose Designed Chiller with the Existing Chiller}

Table 7 gives a comparison of the proposed designed chiller with the old defective one. To cool recycle cyclohexane to $15^{\circ} \mathrm{C}$ using the proposed designed chiller, the chiller capacity increased from 550 TR to 630 TR and compressor duty increases from $1,065,600 \mathrm{~kJ} / \mathrm{h}$ to $1,361,988 \mathrm{~kJ} / \mathrm{h}$ due to the drop in chiller water temperature which increased the evaporator duty. 
Table 6. Valve sizing results.

\begin{tabular}{cc}
\hline Valve sizing parameter and units & Value \\
\hline Inlet pressure $(\mathrm{kPa})$ & 1018.00 \\
Valve opening $(\%)$ & 50.00 \\
$\Delta \mathrm{P}(\mathrm{kPa})$ & 597.1 \\
Flow rate $(\mathrm{kg} / \mathrm{h})$ & $5.224 \times 10^{-4}$ \\
$\mathrm{C}_{\mathrm{v}}(\mathrm{gpm})$ & 46.17 \\
Vapour fraction of refrigerant & 0.2265 \\
\hline
\end{tabular}

Table 7. Comparison of propose designed new chiller with the present chiller.

\begin{tabular}{ccc}
\hline Element/Parameters & Present Chiller & Propose Designed chiller \\
\hline Chiller Capacity (Tons) & 550.00 & 630.00 \\
Compressor Duty $(\mathrm{kJ} / \mathrm{hr})$ & $1,065,600.00$ & $1,361,988.00$ \\
Evaporator duty $(\mathrm{kJ} / \mathrm{hr})$ & $5,245,200.00$ & $7,799,004.00$ \\
Condenser duty $(\mathrm{kJ} / \mathrm{h})$ & $6,310,800.00$ & $9,167,040.00$ \\
Refrigerant flow $\left(\mathrm{m}^{3} / \mathrm{h}\right)$ & 33.00 & 42.2 \\
Suction temperature $\left({ }^{\circ} \mathrm{C}\right)$ & 10.00 & 10.00 \\
Discharge temperature $\left({ }^{\circ} \mathrm{C}\right)$ & 29.26 & 49.53 \\
Chilled water flow $\left(\mathrm{m}^{3} / \mathrm{h}\right)$ & 103 & 120 \\
Condenser cooling water flow $\left(\mathrm{m}^{3} / \mathrm{h}\right)$ & 257 & 372 \\
Valve Coefficient $(\mathrm{gpm})$ & 26.7 & 46.17 \\
\hline
\end{tabular}

The discharge temperature of the designed chiller increased from $29.26^{\circ} \mathrm{C}$ to $49.53^{\circ} \mathrm{C}$ due to rise in compressor work that occurred as a result of increase in refrigerant flow rate from $33 \mathrm{~m}^{3} / \mathrm{h}$ to $42.2 \mathrm{~m}^{3} / \mathrm{h}$. Similarly, the condenser cooling water flow increased from 257 to $372 \mathrm{~m}^{3} / \mathrm{h}$ because of the increased in the rate of heat rejection in the condenser from $6,310,800 \mathrm{~kJ} / \mathrm{h}$ to $9,197,040 \mathrm{~kJ} / \mathrm{h}$.

The compressor power input in the new designed chiller was greater than that of the old chiller because of increased in compression ratio which was as a result of the rise in discharge temperature from $29.3^{\circ} \mathrm{C}$ to $49^{\circ} \mathrm{C}$.

\subsection{Effects of the Proposed Designed Chiller on Cyclohexane Temperature}

Figure 6 shows the temperature shows the temperature profile of cyclohexane as flow of cyclohexane increased when these scenarios were considered; before chiller fault, when defective chiller was bypassed and when the proposed chiller would be in use.

The presence of the chiller caused a temperature drop of up to $23^{\circ} \mathrm{C}$ in the cyclohexane used in ethylene absorption when cyclohexane flow was raised to $200 \mathrm{~T} / \mathrm{h}$. Cyclohexane was discharged to the ethylene absorption unit at $15^{\circ} \mathrm{C}$. This was because greater heat energy was removed from the cyclohexane by 
chilled water, which came from the chiller at a lower temperature of $15^{\circ} \mathrm{C}$.

Figure 6 suggests that when proposed chiller is used, it could give the least outlet temperature of cyclohexane.

\subsection{Effect of Chiller Capacity}

Figure 7 shows the effect of chiller capacity on ethylene absorption rate. The ethylene absorption rate increased from $20 \mathrm{~T} / \mathrm{h}$ to $35 \mathrm{~T} / \mathrm{h}$ when the chiller of 550 TR was used. By interpolation, it could be predicted that with the proposed chiller of 630 TR capacity, ethylene absorption rate would increase to $40 \mathrm{~T} / \mathrm{h}$ as shown in Figure 7. This is because with 630 TR capacity, the cyclohexane would enter the absorption unit at $15^{\circ} \mathrm{C}$ and this would reduce the equilibrium absorption temperature of ethylene [1].

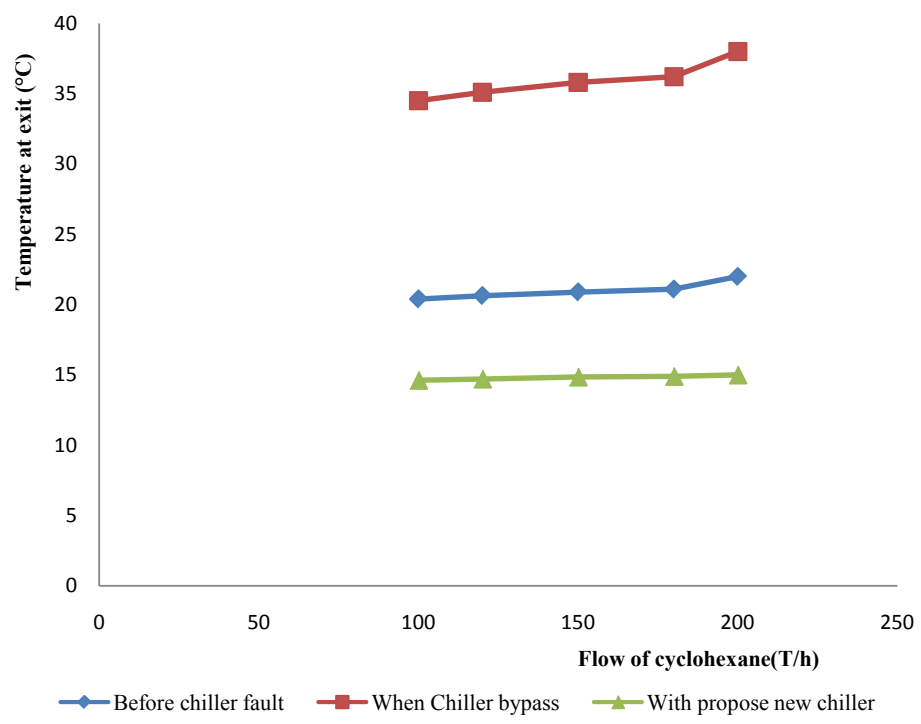

Figure 6. Temperature profile of cyclohexane before chiller fault, when chiller was by-passed, and when proposed chiller would be used.

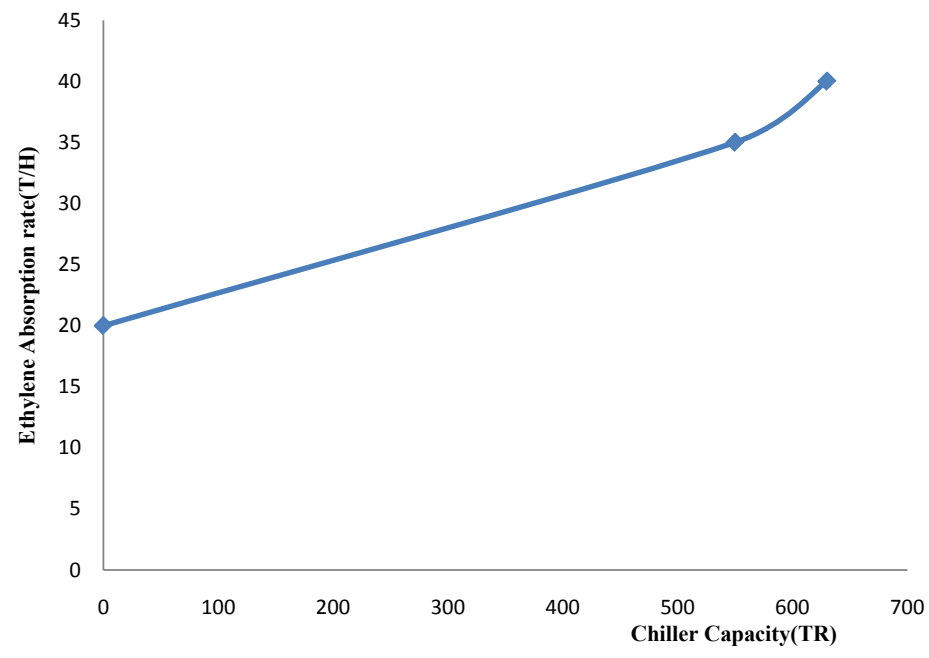

Figure 7. Effect of increase in chiller capacity. 


\section{Conclusions}

A centrifugal water-cooled chiller of 630 tons of refrigeration was designed. The chilled water designed flow rate was $120 \mathrm{~m}^{3} / \mathrm{h}$ at $15^{\circ} \mathrm{C}$. This chiller is capable of cooling $200 \mathrm{~T} / \mathrm{h}$ of cyclohexane at $7 \mathrm{Kg} / \mathrm{cm}^{2}$ from $38^{\circ} \mathrm{C}$ to $15^{\circ} \mathrm{C}$ at the same pressure.

Out of the four refrigerants (R134a, R125, R152a and R1270) used, R134a was the best fit refrigerant for the design. R134a had the least compressor power input requirement at $10^{\circ} \mathrm{C}$ evaporating temperature and thus, gave a chiller with the highest coefficient of performance. R152a had a low compressor input but it is not suitable for evaporation temperature less than $8^{\circ} \mathrm{C}$; a blend of the $\mathrm{R} 134 \mathrm{a}$ and R152a could be used in further studies to see the cooling effect.

The designed chiller had a coefficient of performance of 6.3 and a capacity greater than that of the defective chiller which was $550 \mathrm{TR}$. With the increased cooling capacity and corresponding increased in compressor power from 296 $\mathrm{kW}$ to $378.6 \mathrm{~kW}$, it could discharge chilled water capable of cooling recycle cyclohexane from $38^{\circ} \mathrm{C}$ to $15^{\circ} \mathrm{C}$ without tripping of the unit. Optimization of the designed chiller could be done to further reduce the energy consumption in subsequent studies.

The 630 TR chiller needed a single stage centrifugal compressor with power input of $378.33 \mathrm{~kW}$. The design suction pressure was $414.2 \mathrm{kPa}$, and discharge pressure was $1053 \mathrm{kPa}$, and temperature lift of the chiller was $39.53^{\circ} \mathrm{C}$, while the suction temperature was $10^{\circ} \mathrm{C} .42 .2 \mathrm{~m}^{3} / \mathrm{h}$ of R134a at $10^{\circ} \mathrm{C}$ was needed to absorb $7,799,004 \mathrm{~kJ} / \mathrm{hr}$ heat from $120 \mathrm{~m}^{3} / \mathrm{h}$ chilled water at $31.48^{\circ} \mathrm{C}$. Similarly, 327.2 $\mathrm{m}^{3} / \mathrm{h}$ of cooling water at $30^{\circ} \mathrm{C}$ was needed to eject $9,167,040 \mathrm{~kJ} / \mathrm{hr}$ heat at condenser with a condensing temperature of $40^{\circ} \mathrm{C}$. The maximum condenser water returned temperature was $36^{\circ} \mathrm{C}$. The heat transfer area requirement for the evaporator was $288 \mathrm{~m}^{2}$ while that of condenser was $332.5 \mathrm{~m}^{2}$ (as compared to that of the present defective chiller which is $244 \mathrm{~m}^{2}$ and $319 \mathrm{~m}^{2}$ respectively).

Algorithm was developed for the design procedure and this algorithm was self explanatory and easy to work with.

Finally, although the designed chiller could have cost implications, the chiller would increase the rate of ethylene absorption to $40 \mathrm{~T} / \mathrm{h}$ thereby leading to increase in plant through-put and revenue. Further study can be done to cool the chilled water further and study the effects on the cyclohexane cooling and ethylene absorption rate.

\section{Conflicts of Interest}

The authors declare no conflicts of interest regarding the publication of this paper.

\section{Nomenclature}

\begin{tabular}{cc}
\hline Symbols/abbreviation & Meaning \\
\hline $\mathrm{h}_{\mathrm{f}}$ & Enthalpy of R134a in liquid phase \\
\hline
\end{tabular}




\section{Continued}

\begin{tabular}{|c|c|}
\hline TR & Tons of refrigeration \\
\hline $\mathrm{h}_{\mathrm{g}}$ & Enthalpy of Refrigerant in gaseous phase \\
\hline R134a & 1,1,1,2-tetraflouroethane \\
\hline R1270 & Propylene \\
\hline R125 & 1,1,12,2-pentaflouroethane \\
\hline R152a & 1,1-diflouroethane \\
\hline $\mathrm{T}_{\mathrm{d}}$ & Discharge Temperature \\
\hline $\mathrm{R}$ & Compression ratio \\
\hline$\gamma$ & Ratio of heat capacities \\
\hline $\mathrm{T}_{\mathrm{s}}$ & Suction temperature \\
\hline $\mathrm{P}$ & Pressure \\
\hline $\mathrm{H}$ & Enthalpy \\
\hline $\mathrm{U}$ & Internal energy \\
\hline $\mathrm{V}$ & Volume \\
\hline Rev & Reversible \\
\hline$\eta$ & Efficiency \\
\hline $\mathrm{W}_{\mathrm{c}}$ & Compressor work \\
\hline $\mathrm{W}_{\mathrm{s}}$ & Real work \\
\hline$\dot{m}$ & Mass flow rate \\
\hline$\Delta$ & Change \\
\hline $\mathrm{C}_{\mathrm{p}}$ & Specific heat capacity t constant pressure \\
\hline $\mathrm{C}_{\mathrm{v}}$ & Specific heat capacity t constant volume \\
\hline $\mathrm{R}$ & Universal gas constant \\
\hline Isen & Isentropic \\
\hline $\mathrm{M}_{\mathrm{R}}$ & Mass flow of refrigerant \\
\hline$Q_{\text {evap }}$ & Evaporator duty \\
\hline $\mathrm{Q}_{\text {cond }}$ & Condenser duty \\
\hline S & Enthropy \\
\hline TXV & Thermal Expansion valve \\
\hline U & Coefficient heat transfer \\
\hline A & Area \\
\hline COP & Coefficient of performance \\
\hline $\mathrm{T} / \mathrm{h}$ & Tones per hour \\
\hline $\mathrm{X}$ & Quality of refrigerant \\
\hline $\mathrm{Cv}$ & Valve flow Coefficient \\
\hline $\mathrm{N}_{\mathrm{t}}$ & Number of tubes \\
\hline $1,2,3,4$ & States on P-h diagram \\
\hline$\rho$ & Density \\
\hline $\mathrm{C}_{6} \mathrm{H}_{12}$ & Cyclohexane \\
\hline
\end{tabular}




\section{References}

[1] Marshal, I. (1991) Schlairtech Process Technology [Plant Training Manual]. Polyethylene Plant, Eleme Petrochemicals Company Limited Port Harcourt.

[2] Tommaso, C., Frans, V., Maryam, T., Nicolaas, F., Francesco, B., Giuseppe, S. and Massimo, M. (2018) The Effect of Residence Time Distribution on the Slurry-Phase Catalytic Ethylene Polymerization: An Experimental and Computational Study. Macromolecular Engineering, 12, 3.

[3] Atan, M., Hussain, M., Abbasi, R., Khan, M. and Fazly Abdul Patah, M. (2019) Advances in Mathematical Modeling of Gas-Phase Olefin Polymerization. Process, 7, 67. https://doi.org/10.3390/pr7020067

[4] Rajput, R.K. (2008) Heat and Mass Transfer in SI Units. $2^{\text {nd }}$ Ed., S. Schand \& Company PVT. Ltd., New Delhi.

[5] Jayesh, S.A. and Neeraj, K.C. (2014) Design and Performance Analysis of Water Chiller-A Research. International Journal of Engineering Research and Applications, 4, 19-25.

[6] Shan, K.W. (2000) Handbook for Air Conditioning and Refrigeration. $2^{\text {nd }}$ Ed., Mc Graw Hills Publications, New York.

[7] Hart, I. (2005) Engineering Thermodynamics, a First Course. Gen Computer Solution, Port Harcourt.

[8] Smith, J.M., Van-Ness, H.C. and Abbott, M.M. (2005) Introduction to Chemical Engineering Thermodynamics. $7^{\text {th }}$ Ed., Mc Graw-Hills Publications, New York.

[9] Campbel, J.M. (2014) Gas Conditioning and Processing: The Equipment and Modules. $9^{\text {th }}$ Ed., Vol. 2, Norman, Oklahoma.

[10] Tony, G. (2010) Compressor Handbook: Principles and Practice. The Fairmont Press, Inc., New Delhi.

[11] Desai, P.S. (2004) Modern Refrigeration \& Air Conditioning for Engineers. Khanna Publishers, New Delhi.

[12] Sinnott, R. and Gavin, T. (2009) Chemical Engineering Design. $5^{\text {th }}$ Ed., Vol. 6, Burlington, USA.

[13] Engineering Tool Box. (2018) Resources, Tools and Basic Information for Engineering and Design of Technical Applications. http://www.engineeringtoolbox.com/

[14] Cao, Y., Huang, L.Q., Cui, Z.G. and Liu, J. (2018) The Optimal Operation of Cooling Tower Systems with Variable Frequency Control. IOP Conference Series: Earth and Environment, 113, Article ID: 012085.

[15] American Society of Heating, R.A.A.E. (2013) 2013 ASHRAE Handbook: Fundamentals (Inch-Pound Ed.) ASHRAE, Atlanta, GA. 